\title{
A NEW SPECIES OF NEPENTHES (NEPENTHACEAE) AND ITS NATURAL HYBRIDS FROM ACEH, SUMATRA, INDONESIA
}

Received December 22, 2020; accepted June 22, 2021

\author{
MALCOLM VICTORIANO \\ Indonesian Carnivorous Plant Society. Jln. Manggis 52, Jakasetia, Bekasi City, 17147, Indonesia. \\ Email: malcolm.victoriano@gmail.com
}

\begin{abstract}
VICTORIANO, M. 2021. A new species of Nepenthes (Nepenthaceae) and its natural hybrids from Aceh, Sumatra, Indonesia. Reinwardtia 20(1): 17-26. - A new species of Nepenthes (Nepenthaceae) from Aceh Province, Indonesia, Nepenthes longiptera Victoriano is herein described and illustrated. The species is unique among all other Nepenthes in Sumatra by the presence of wings on its upper pitchers. Comprehensive description, photographs, geographical distribution and preliminary IUCN conservation assessment are provided for the new species. Hybrids of this new taxon with other species are also reported in this paper.
\end{abstract}

Key words: Aceh, carnivorous plant, Nepenthes, new species, Sumatra.

\begin{abstract}
ABSTRAK
VICTORIANO, M. 2021. Satu jenis baru Nepenthes (Nepenthaceae) dan silangan-silangan alaminya dari Aceh, Sumatra, Indonesia. Reinwardtia 21(1): 17-26. - Satu jenis baru Nepenthes (Nepenthaceae) dari Provinsi Aceh, Indonesia, Nepenthes longiptera Victoriano telah dipertelakan dan digambarkan. Jenis ini berbeda dari semua jenis $\mathrm{Ne}$ penthes lainnya di Sumatra dengan adanya sayap di kantong atasnya. Pertelaan lengkap, wilayah persebaran dan taksiran awal status konservasi IUCN telah disajikan untuk jenis baru ini. Silangan-silangan alami jenis baru ini dengan jenis lain juga dilaporkan dalam makalah ini.
\end{abstract}

Kata kunci: Aceh, jenis baru, Nepenthes, Sumatra, tumbuhan karnivora.

\section{INTRODUCTION}

Nepenthes L. is a carnivorous plant genus from the old world and is classified as the only existing genus of the family Nepenthaceae Dumort. The genus consists of 168 accepted species (POWO, 2021) and the number is increasing as almost every year, several new taxa have been described. For example, Robinson et al. (2019) described a new species $N$. dactylifera A.S.Rob., Golos, S.McPherson \& Barer from Borneo which was mentioned earlier as Nepenthes sp. Bagong in a paper which also provides the revision of $N$. $z a-$ kriana (J.H.Adam \& Wilcock) J.H.Adam \& Hafiza, N. fusca Danser. Later, Golos et al. (2020), described a new species of Nepenthes of Indonesian Borneo named as $N$. fractiflexa Golos, A.S.Rob. \& Barer.

Sumatra island is the second largest diversity centre of Nepenthes species number recorded, compared with the next richest island: Borneo. Several Nepenthes experts have claimed that Sumatra is a hotspot of Nepenthes evolution and the number of endemic species from Sumatra is higher than Borneo (Wistuba et al., 2007). With such high diversity, Sumatra island is believed to still have several undiscovered taxa (Wistuba et al., 2007). The taxonomy of Sumatran Nepenthes, however, has never been systematically revised and is poorly known. Species delimitation and nomenclature of several species have been controversial, such as $N$. junghuhnii MacFarl. ex Ridl.

In 2019, the author had an opportunity to record the diversity of Nepenthes spp. in their natural habitat during a fieldwork in Nagan Raya Regency, Aceh Province. The author successfully recorded several Nepenthes species and its hybrids. After we visited several locations in Central Aceh and Nagan Raya Regency, the author discovered an unusual Nepenthes species that appeared to be new, then it was labelled as Nepenthes sp. Aceh. This taxon is very distinct from any other Nepenthes species known from Sumatra. For several years before, the local orchid hunters were gathering these plants from the jungle and sold them to local people as Nepenthes sp. 'Dairi' for decoration purpose. They consider that name because it resembles to an unidentified Nepenthes taxon from Dairi Regency in North Sumatra Province, although the plants were not exported from Dairi Regency. Further information will be explained in the discussion below.

The new species described in this paper was collected from roadside near copper mine and coffee (Coffea canephora L.) plantations in Nagan Raya Regency, Aceh Province, Indonesia. Since there are massive land clearings happened in $\mathrm{Su}-$ 
Table 1. Nepenthes that are found in Aceh Tengah and Nagan Raya Regency during the trip.

\begin{tabular}{lll}
\hline Species & Altitude $(\mathrm{m})$ & Habitat \\
\hline N. lavicola & $800-2,200$ & $\begin{array}{l}\text { This species grows widely in Aceh highlands as terrestrial at } \\
\text { river banks, cliffs, swamps, pine forests, grassland and even } \\
\text { on the roadside. It occasionally grows as an epiphyte in mossy } \\
\text { forest } \\
\text { Mostly found in open area growing on sedimentary or lava } \\
\text { rocks and highland swamps }\end{array}$ \\
N. mikei & $750-2,200$ & $\begin{array}{l}\text { Although it is a common species, it is rarely found in higher } \\
\text { altitude in this area. Only known in open area near the copper } \\
\text { mining }\end{array}$ \\
N. reinwardtiana & $200-800$ & $\begin{array}{l}\text { This species favours wet habitat such as swamps, river banks } \\
\text { and sewerage. They are growing sympatrically with other } \\
\text { species mentioned above except } N \text {. mikei } \\
\text { The type is known from Nagan Raya Regency, it is growing } \\
\text { as terrestrial in humus with the colony of ferns or in grassland } \\
\text { near the roadside }\end{array}$ \\
\hline $7,200-1,600$. Aceh & $750-1,600$ & \\
\hline
\end{tabular}

matra, a lot of plant species from the inaccessible forest are discovered. This event gives the opportunity to the explorers to discover the diversity in the forest of Aceh, but unfortunately this is also considered as a threat to the natural habitat in that area. This situation gives an opportunity to local people to collect the plants for medicine and decorative purposes.

\section{MATERIALS AND METHODS}

To get the data, the author examines the material from type locality. During six days of exploration, the author was able to locate several well-known Nepenthes species in Aceh. In the habitat, the author examined this taxon by taking the measurements, elevation, ecology and population for assessing the conservation status. The data was then compared with other species of Nepenthes both in natural habitat and cultivation for comparative study of the new species morphology.

\section{RESULTS AND DISCUSSION}

Several known species of Nepenthes have been discovered during this survey. There are at least eight species of Nepenthes that can be discovered in Aceh, it includes $N$. lavicola Wistuba \& Rischer (Wistuba \& Rischer, 1996), N. ampullaria Jack, $N$. densiflora Danser, $N$. diatas Jebb \& Cheek, N. mikei B.R.Salmon \& Maulder, N. mirabilis (Lour.) Rafarin, $N$. spectabilis Danser and $N$. tobaica Danser (Jebb \& Cheek, 1997). According to McPherson (2009) there are no natural hybrid has been recorded in Aceh highland before, most of Nepenthes species in Aceh grow in separate area and rarely encounter to each other, thus natural hybridisation is rarely known. During the survey to the new locations, the author successfully located five Nepenthes species and their natural hybrids, including a new species that also hybridised with other species. A hybrid with multiple parent species is also recorded. Nepenthes that are found during the survey are $N$. lavicola, $N$. mikei, $N$. reinwardtiana and $N$. tobaica (see Table 1 and Fig. 1). All these species at least have been hybridised with one species. But some related species such as $N$. mikei, $N$. reinwardtiana and $N$. tobaica are found to grow separately to each other. Nepenthes in Aceh mostly grow in highland swamp forests or swamps with Sphagnum sp., in this type of habitat the population is very dense, more than in other type of habitat, such as in lowland rainforests, sedimentary rocks formation, river banks, grasslands or field. The examined materials consist of an undescribed Nepenthes and its putative hybrids for morphological study collected during a field survey in Aceh, Sumatra, Indonesia. This taxon was labelled as Nepenthes sp. Aceh, and about 102 specimens were seen in the habitat. Type materials of the new species are deposited in Herbarium Bogoriense (BO).

Nepenthes longiptera Victoriano spec. nov. Figs. $3 \& 4$.

- TYPE: INDONESIA, Sumatra, Aceh Province, Nagan Raya Regency, Beutong. At elevation $c a$. 780 m, 13 February 2019, Victori 001. Holotype BO (climbing plant with 2 upper pitchers and 1 


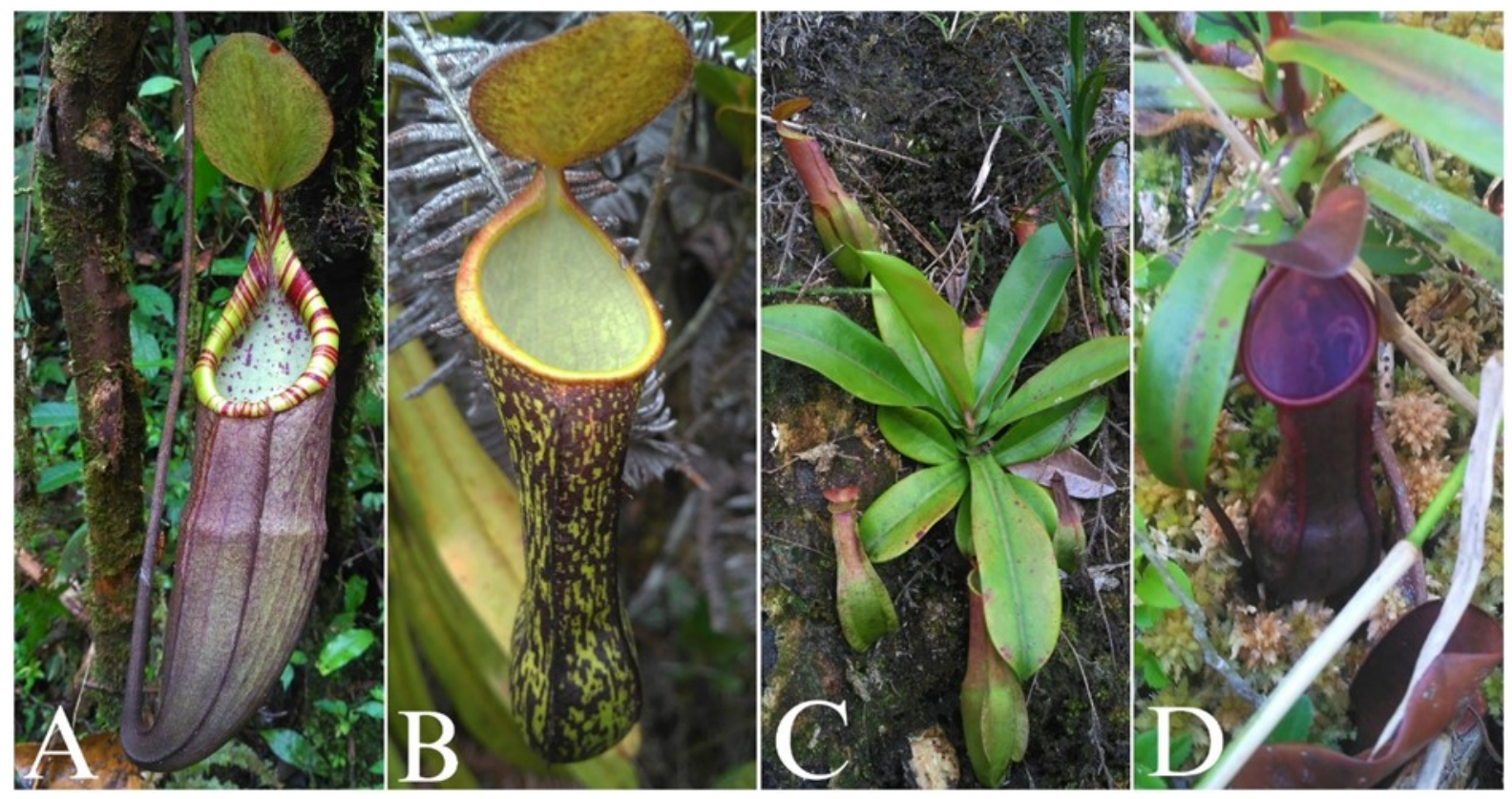

Fig. 1. Nepenthes spp. occurred in Aceh Tengah Regency and Nagan Raya Regency. A. N. lavicola. B. N. mikei. C. $N$. reinwardtiana. D. $N$. tobaica. The specimens were photographed only. Photos by Malcolm Victoriano.

male inflorescence, incl. an allotype: 1 infructescence); isotype $\mathrm{BO}$ (stem with lower pitchers).

Nepenthes longiptera is similar to $N$. tobaica but differs in having larger habit, with well developed upper pitcher wings ( $N$. tobaica: reduced to ribs); rhomboid stem in cross-section ( $N$. tobaica: obtusely triangular); and the presence of an appendage under the lid (N. tobaica: absent).

A climbing, terrestrial plant with $1-5$ basal shoots, up to $13 \mathrm{~m}$ long, the whole plant mostly pubescent. Stem rhomboid in transection with diameter of 12 $\times 9 \mathrm{~mm}$, internodes in vining plant $3-11 \mathrm{~cm}$ long, occasionally bearing an elongated dormant bud on each leaf axillary. Young shoots covered in thin brown caducous bristles so plants appear to be glabrous when mature. Leaves coriaceous, oblong or lanceolate; contracted into linear at the base, 27 $-33 \mathrm{~cm}$ long and $4.4-6 \mathrm{~cm}$ wide, leaves sessile in the immature plant, leaf attachment amplexicaulate, auriculate at the base; clasping $2 / 3$ of the stem, leaf apex variable even in the same plant; mostly obtuse, acute with retuse, subpeltate or uneven tip, the surface of the leaf blade become glabrous but the base of midrib still pubescent with indistinct pinnate veins on either side of the midrib, slightly undulate. Leaves of the rosettes and climbing stems similar. Lower pitchers pubescent, narrowly infundibular at the basal part, cylindrical at the upper part, $40 \mathrm{~cm}$ long, $7-8 \mathrm{~cm}$ in diameter, a pair of fringed wings runs down the pitcher's ventral surface, $10-12 \mathrm{~mm}$ wide, pitcher's opening ovate, narrower than the upper pitchers, $8 \times 4 \mathrm{~cm}$, the waxy zone inside can be white or speckled, sometimes bearing two eye spots. Operculum narrowly ovate, slightly cordate at the base, $6 \times 5$ $\mathrm{cm}$, the upper part slightly jutted on its 2 pinnate veins, the whole surface pubescent at the top; glabrous at the bottom but pubescent at the bottom apex. Appendage present on the underside of the lid near the base, $3 \mathrm{~mm}$ long, covered with circular glands, less than $1 \mathrm{~mm}$ in diameter. Spur occasionally branched or filiform, $1-2.6 \mathrm{~cm}$ long. Tendril $3 / 4$ long of the pitcher, inserted on the left or right side of the pitcher. The colour varies from red, to pinkish or orange with red speckles. Upper pitchers pubescent, slender, urceolate in its basal half; becoming cylindrical above and slightly infundibular towards the peristome, reaching up to $45 \mathrm{~cm}$ in height and $7 \mathrm{~cm}$ wide, a pair of fringed wings always present in the upper pitcher, 10-12 mm wide, with 6-12 $\mathrm{mm}$ long bristle, the base of the bristle triangular. Pitcher opening widely obovate, $8 \mathrm{~cm}$ long; $5.5 \mathrm{~cm}$ wide. Peristome flattened, up to $6 \mathrm{~mm}$ wide, and has a distinct raised section at the front, often with red notches. Operculum ovate to orbiculate, $6 \times 6.5$ $\mathrm{cm}$, slightly domed, the whole surface pubescent at the top; glabrous at the bottom but pubescent at the apex. Appendage present on underside lid near the base, $4 \mathrm{~mm}$ wide, the appendage covered with less than $1 \mathrm{~mm}$ circular nectar glands. Spur unbranched, $1-2.5 \mathrm{~cm}$ long, slightly flattened, being inserted $12 \mathrm{~mm}$ away under the lid base. Tendril slightly longer than the pitcher, some as long as the pitcher, coiled, with diameter of $1.5-3 \mathrm{~mm}$, usually pure green when fully mature. Male 


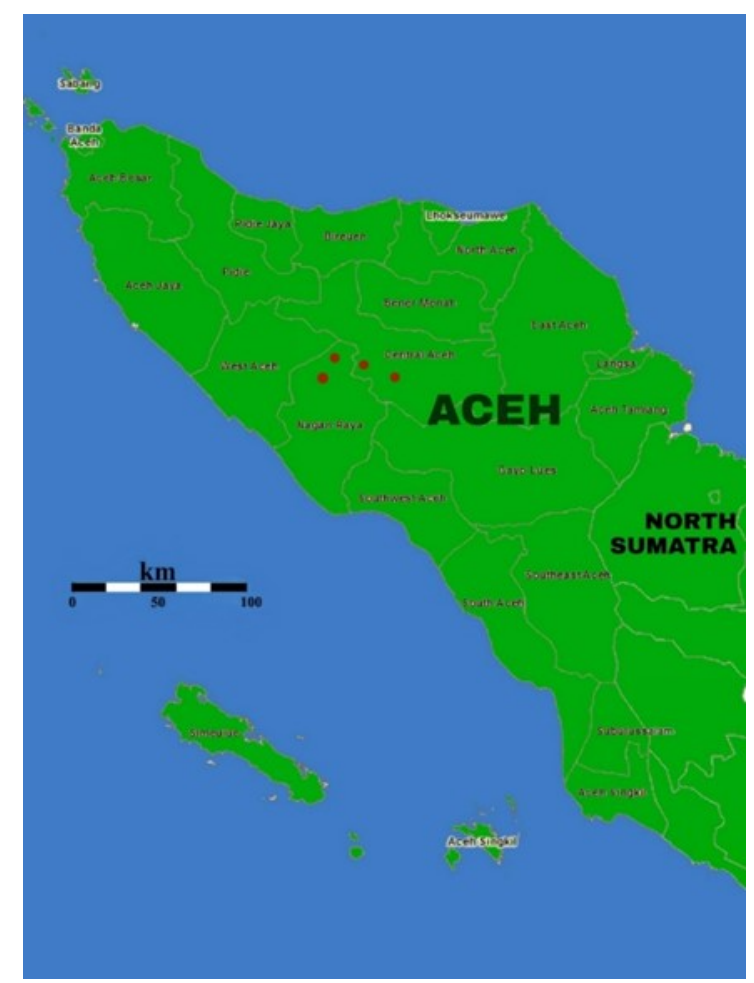

Fig. 2. Distribution of Nepenthes longiptera in Aceh, Indonesia. Red dots: location where the plants are observed and collected.

inflorescence up to $1 \mathrm{~m}$ long, with $c a .240$ flowers, peduncle $40 \mathrm{~cm}$, bract linear, $2 \mathrm{~mm}$ long, partial peduncle two-flowered 4-6 mm long, pedicles 11$15 \mathrm{~mm}$, less than $1 \mathrm{~mm}$ in diameter at the base, staminal column 5-6 mm long, anther head 1.5 $\mathrm{mm}$ in diameter, tepals elliptic, $4 \times 2 \mathrm{~mm}$, green or yellowish and turns into pink at the margin during anthesis. Female inflorescence up to $60 \mathrm{~cm}$ long, with $c a$. 80 flowers, peduncle $36 \mathrm{~cm}$ long, bract not prominent, partial peduncle two-flowered 8-12 $\mathrm{mm}$ long, less than $1.5 \mathrm{~mm}$ diameter at the base, pedicles $3-9 \mathrm{~mm}$, tepals elliptic, $5 \times 2 \mathrm{~mm}$, ovary unknown. Fruits valves 4 , narrowly linearelliptic, 34-40 $\mathrm{mm}$ long, $4 \mathrm{~mm}$ in diameter, bearing 50-90 winged seeds. Seed fusiform with 2 filiform wings $15-20 \mathrm{~mm}$ long from tip to tip.

Distribution. This species is only found in its type locality, in intermediate to highland rainforest of Nagan Raya Regency and nearby area in Aceh province, Sumatra, Indonesia.

Habitat and Ecology. Terrestrial in the rainforest, mostly associated with a colony of fern Dicranopteris linearis (Burm.f.) Underw., in open area or under shade in humus or clay-based medium, at altitude $750-1,600 \mathrm{~m}$ above sea level. Usually growing in open area with high exposure of sunlight. Plants that grow under shade or dense vegetation tend to be smaller and elongated.

Proposed Conservation Status. Following the
Red List criteria of the IUCN Standards and Petitions Subcommittee (2019), the author assessed Nepenthes longiptera as Endangered (EN) $\mathrm{C} 2 \mathrm{ab}(\mathrm{i})$. Nepenthes longiptera only known from restricted area less than $30 \mathrm{~km}^{2}$ with $c a .200$ observed mature individuals. This area is not protected and the habitat is threatened by the activity of gold/copper mining and coffee plantation.

Etymology. From Latin longus means long and Latinised Greek pteron means wing; referring to the presence of a relatively long pair of wings of the upper pitchers, it runs down from below the peristome to the apex of the tendril. It is resembling the fins of Long-Finned Prickleback fish, Xenolumpenus longipterus Shinohara \& Yabe.

Hybrids. Nepenthes longiptera is recorded to grow sympatrically with some Sumatran species, mostly with $\mathrm{N}$. tobaica then $N$. lavicola, rarely with $N$. mikei and $N$. reinwardtiana. This makes natural hybrid possible and the author recorded four putative natural hybrids in habitat (see Table 3 \& Fig. 5). A putative hybrid of $N$. longiptera with $N$. reinwardtiana also occurred. The record is based on a photograph from a hobbyist in Aceh. These natural hybrids occurrence is rather rare compared to their parent species, even though the phenology is occurring at the same time. The population of the parent species are abundant and grow sympatrically. This situation makes the 

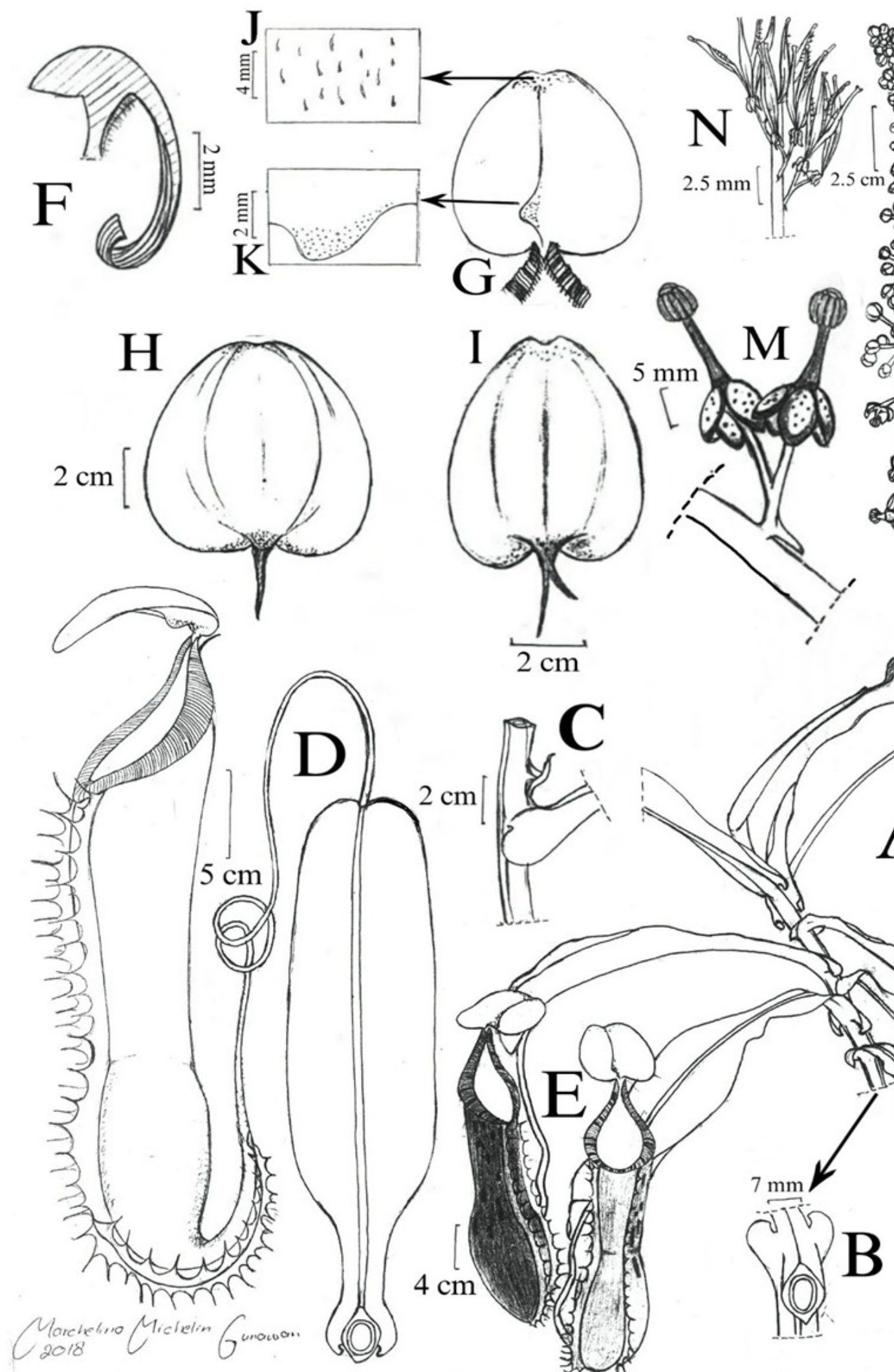

$\mathrm{M}$
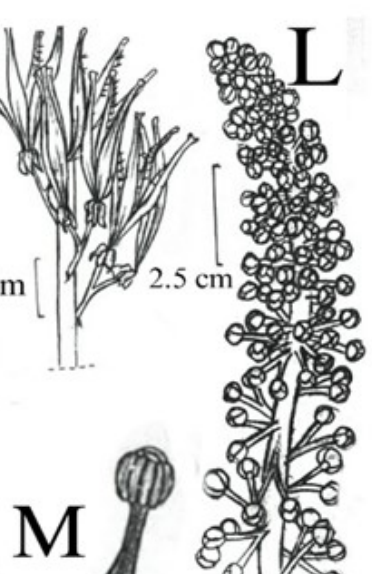

(1)


Fig. 3. Nepenthes longiptera Victoriano, spec. nov. A. Habitus. B. Stem transection with leaf attachment. C. Axillary dormant bud. D. Leaf with an upper pitcher. E. Lower pitchers. F. Peristome transection, the inner side is on the left side. G. Lid (underside). H. Lid of aerial pitcher with a simple spur. I. Lid of basal pitcher with a forked spur. J. Bristles underside the lid. K. Appendage with glands. L. Male inflorescence. M. Male flowers. N. Infructescence. From Victori 001, drawn by Marchelino Michelin Gunawan. 

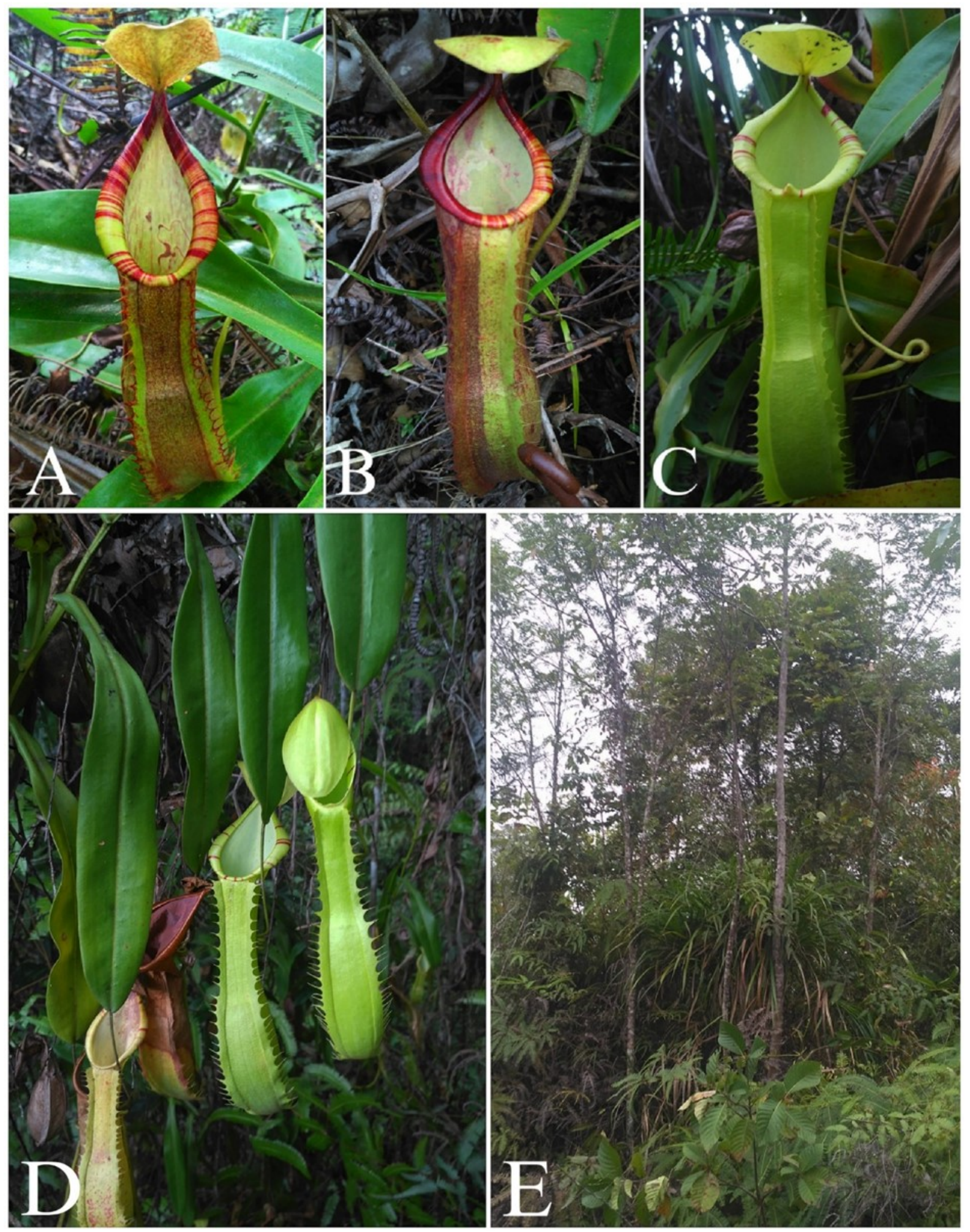

Fig. 4. Nepenthes longiptera Victoriano spec. nov., A. Lower pitcher, mostly bright in colour, ranging from red to orange, or red with speckles. B. Intermediate pitcher, the transition from lower to upper pitcher, usually still retains the colouration of lower pitchers. C. Upper pitcher, with its unique characteristic that still has wings which mostly reduced to ribs in other species, the colour is pure green when mature. D. Vining plant with upper pitcher in locus classicus. E. Typical habitat of $N$. longiptera in the colony of fern Dicranopteris linearis and small trees. Photos by Malcolm Victoriano. 
Table 2. The morphological characters used to distinguish Nepenthes longiptera, N. tobaica, N. mikei and N. reinwardtiana (similar sympatric species).

\begin{tabular}{|c|c|c|c|c|}
\hline Characters & N. longiptera & N. tobaica & N. mikei & N. reinwardtiana \\
\hline Upper wings & $\begin{array}{l}\text { Present and well } \\
\text { developed }\end{array}$ & Reduced to ribs & Reduced to ribs & Reduced to ribs \\
\hline $\begin{array}{l}\text { Shape of upper } \\
\text { pitcher }\end{array}$ & $\begin{array}{l}\text { Slender, urceolate } \\
\text { in its basal half; } \\
\text { becoming cylindri- } \\
\text { cal above and } \\
\text { slightly infundibu- } \\
\text { lar towards the pe- } \\
\text { ristome }\end{array}$ & $\begin{array}{l}\text { Somewhat infun- } \\
\text { dibular in the } \\
\text { lowermost part, } \\
\text { becoming narrowly } \\
\text { ovoid in the lower } \\
\text { third, and finally } \\
\text { cylindrical and } \\
\text { slightly narrower } \\
\text { above }\end{array}$ & $\begin{array}{l}\text { Ovate in their ba- } \\
\text { sal } 1 / 3 \text { to } 1 / 5, \text { becom- } \\
\text { ing cylindrical } \\
\text { above and infun- } \\
\text { dibular towards } \\
\text { the peristome }\end{array}$ & $\begin{array}{l}\text { Urceolate in its } 1 / 3 \text { to } \\
1 / 2 \text { basal part, tri- } \\
\text { angular, becoming } \\
\text { slightly infundibular } \\
\text { in the upper part }\end{array}$ \\
\hline
\end{tabular}
Shape of lower
pitcher

$\begin{aligned} \text { Upper pitcher lid } & \begin{array}{l}\text { Ovate-orbicular } \\ \text { with cordate base, } \\ \text { slightly domed } \\ \text { with appendage on } \\ \text { lower surface }\end{array}\end{aligned}$

Lower pitcher lid Elliptic with cordate base, flat with appendage

The basal part is narrowly infundibular, upper part is cylindrical

Ovoid in the lower portion and cylindrical above

Ovate to suborbicular and has a somewhat cordate base, lack of appendage

Ovate to suborbicular and has a somewhat cordate base, lack of appendage.

Stem Rhomboid

Leaf shape

Leaf attachment

Oblong, subpetiolate

Similar to the lid of the upper pitchers.

Ovate and has a cordate base, lack of appendage

basal part, cylindrical and infundibular towards the pitcher mouth

Ovate in its $1 / 3$ to $1 / 2$ basal part, cylindrical above

Elliptic, flat, lack of appendage

Similar to the lid of the upper pitchers
Oblong to spathulate

Linear
Cylindrical to ob- Cylindrical to tusely triangular
Triangular to obtusely triangular

Lanceolate to subspathulate

Sessile, clasping $1 / 2$ of the stem. petiolate, clasping $1 / 2$ of stem (Clarke, 2001)
Sessile to decurrent (McPherson, 2009)
(Salmon \& Maulder, 1995) riculate, clasping $2 / 3$ of the stem 
Table 3. Putative hybrids of Nepenthes that are encountered in Aceh Tengah and Nagan Raya Regency.

\begin{tabular}{lll}
\hline \multicolumn{1}{c}{ Parentage } & Altitude $(\mathrm{m})$ & \multicolumn{1}{c}{ Habitat } \\
\hline N. lavicola $\times N$. longiptera & $\sim 1,380$ & $\begin{array}{l}\text { Only known from single location in a highland swamp with } \\
\text { Sphagnum moss }\end{array}$ \\
N. lavicola $\times$ N. mikei & $1,600-1,720$ & $\begin{array}{l}\text { Growing in open area where both parents grow sympatrically } \\
\text { in swamp forest with stunted trees }\end{array}$ \\
$N$. lavicola $\times N$. tobaica & $1,400-1,600$ & $\begin{array}{l}\text { Growing on understory of swamp forest, this hybrid is rarely } \\
\text { occurred, even hundreds of both parents species colonies are } \\
\text { mixed well in same area }\end{array}$ \\
N. longiptera $\times N$. tobaica & $\sim 1,420$ & $\begin{array}{l}\text { This hybrid grows on lavarock in open area near the mining } \\
\text { area }\end{array}$ \\
\hline
\end{tabular}
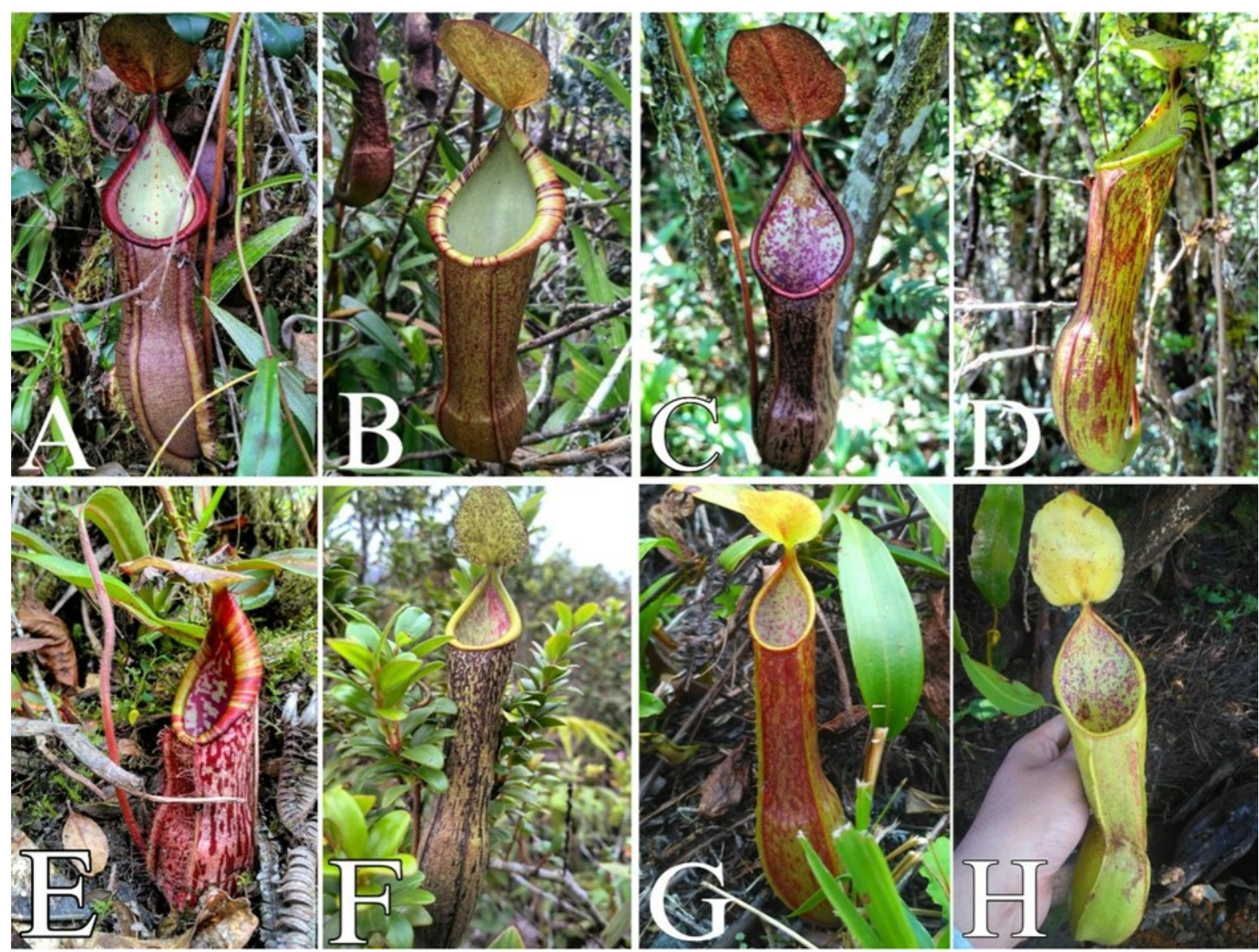

Fig. 5. Putative natural hybrids of Nepenthes that probably only occur in Aceh. A-B. N. lavicola $\times$ N. longiptera. A. Lower. B. Upper. C-D. N. lavicola $\times$ N. tobaica. C. Lower. D. Upper. E-F. $N$. lavicola $\times N$. mikei. E. Lower. F. Upper. G-H. N. tobaica $\times$ N. longiptera. G. Lower. H. Upper. Photos by Malcolm Victoriano. 
hybridisation possible, but according to the observation in the habitat, the result of cross pollination are very low compared to same species pollination. From a hundreds of mature individuals of different species in a small area, there is usually only one hybrid which shared the characteristics from both species. This can be spotted as a result of cross pollination, which is a strong evidence of this putative hybrid, because a single specimen can not sustain its population to reproduce, thus this is not a pure species. They are usually spotted not far from their female specimens. There is also a new record of hybrid between N. lavicola and $N$. tobaica in Aceh, but interestingly hybrid plants such as $N$. mikei $\times N$. tobaica, $N$. mikei $\times N$. reinwardtiana and $N$. tobaica $\times N$. reinwardtiana are possibly non existent because these species grow separately in Aceh, and probably their habitat is not overlapping.

Notes. Nepenthes longiptera is previously known as an unidentified Nepenthes sp. with a trade name $N$. sp. 'Aceh' in carnivorous plants community. This species was thought to be conspecific with another unknown Nepenthes under the trade name 'Dairi' (named after the locality where it was collected) which already exist in cultivation since 2007. However, the author can not conclude whether it is the same or not as further examination on the materials from Dairi is necessary. The specimens from Dairi tend to be smaller than those from Aceh, the leaves more linear, and the upper pitchers are rarely seen, their lower pitchers are sometimes green, these characteristics are unusual for $N$. longiptera.

\section{CONCLUSION}

Nepenthes longiptera is a new species from Aceh, Sumatra, Indonesia. It is similar to N. tobai$c a$ but differs in having larger habit, with well developed wings on upper pitcher ( $N$. tobaica: reduced to ribs); rhomboid stem in cross-section ( $N$. tobaica: obtusely triangular); and the presence of an appendage under the lid ( $N$. tobaica: absent). This new species is probably endemic to Aceh province and only known from Nagan Raya and Central Aceh Regency. It has several putative natural hybrids with other Sumatran species which are never been recorded in Aceh before. Some Acehense species such as N. lavicola, N. mikei and $N$. tobaica are abundant in highland forests but these species had been recorded with no hybrid with other species in this area (McPherson, 2009).

\section{ACKNOWLEDGEMENTS}

The author is indebted to Wewin Tjiasmanto for his intellectual and financial support for making this research possible. The author also would like to thanks Marchelino Michelin Gunawan for drawing the botanical illustration, Rohman, Alfajar, Wibowo Aji and team for accompanying the author during the field trip, Mark Arcebal Kling Naive and Frankie Handoyo for his assistance.

\section{REFERENCES}

CLARKE, C. M. 2001. Nepenthes of Sumatra and Peninsular Malaysia. Natural History Publications (Borneo), Kota Kinabalu.

GOLOS, M. R., ROBINSON, A. S., BARER, M., DANČÁK, M., DE WITTE, J., LIMBERG, A., SAPAWI, N. B. M. \& TJIASMANTO, W. 2020. Nepenthes fractiflexa (Nepenthaceae), a new Bornean pitcher plant exhibiting concaulescent metatopy and high degree of axillary bud activation. Phytotaxa 432(2): 125-143.

IUCN Standards and Petitions Subcommittee 2019. Guidelines for Using the IUCN Red List Categories and Criteria. Version 14. Available from: http://www.iucnredlist.org/documents/ RedListGuidelines.pdf. (Accessed 1 October 2020).

JEBB, M. H. P. \& CHEEK, M. R. 1997. A skeletal revision of Nepenthes (Nepenthaceae). Blumea 42(1): 1-106.

MCPHERSON, S. R. 2009. Pitcher Plants of the Old World. 2 volumes. Redfern Natural History Productions, Poole.

POWO. 2021. Plants of the World Online. Facilitated by the Royal Botanic Gardens, Kew. Published on the Internet; http:// www.plantsoftheworldonline.org/ (Retrieved 06 07 2021).

ROBINSON, A. S., GOLOS, M. R., BARE, M., SANO, Y., FORGIE, J. J., GARRIDO, D., GORMAN, C. N., LUICK, A. O., NICK, W. R., MCINTOSH, N. W. R., MCPHERSON, S. R., PALENA, G. J., PANČO, I., QUINN, B. D. \& SHEA, J. 2019. Revisions in Nepenthes following explorations of the Kemul Massif and the surrounding region in North-Central Kalimantan, Borneo. Phytotaxa 392(2): 97-126.

SALMON, B. R. \& MAULDER, R. G. 1995. Two new species of Nepenthes from North Sumatra, Indonesia. Carnivorous Plant Newsletter 24(3): 77-85. 
WISTUBA, A., NERZ, J. \& FLEISCHMANN, A. 2007. Nepenthes flava, a new species of Nepenthaceae from the northern part of Sumatra. Blumea 52(1): 159-163.
WISTUBA, A. \& RISCHER, H. 1996. Nepenthes lavicola, a new species of Nepenthaceae from the Aceh Province in the north of Sumatra. International Carnivorous Plant Society 25(4): 106-111. 